\title{
REVIEW: EKSPLORASI KETERKAITAN VERTIKAL ANTARA AKTIVITAS DEPARTEMEN SDM-STRATEGI SDM PERUSAHAAN
}

\author{
A Review: Exploring The Importance Of Human Resource Activities-Strategies \\ Alignments.
}

\author{
Silva Latisya \\ Bogor \\ Magister Manajemen, Sekolah Bisnis IPB, IPB University
}

\begin{abstract}
This study aims to explore the vertical alignments between $H R$ department activities and the company's HR strategy. The goal of this study is to ensure how HR activities can be aligned with HR strategies to enhance the HR department works in the context of achieving company goals. The study was conducted by depth discussion of scientific journals that have been written with interactive group brainstorming approach, consisting of 21 students into three groups to discuss and generate ideas about $H R$ activities and their strategic relationships while researchers guide and provide the materials needed. The group identified and agreed on seven HR activities including job design; mobilization; selection; retention and separation; performance management; employee training; and compensation, and aligned with each of the four HR strategies identified including the Bargain Laborer; Free Agent; Loyal Soldier; and Committed Expert. The results of the study revealed the relevance of the activities of the HR department with the company's HR strategy. Total organizational performance also be positively influenced by HR activities through the company's HR strategy.
\end{abstract}

Keywords: HR activities; interactive brainstorming groups; HR strategies; vertical HR alignment, organizational performance

\begin{abstract}
ABSTRAK: Studi ini bertujuan untuk mengeksplor dan membahas secara mendalam mengenai keterkaitan secara vertikal antara kegiatan-kegiatan departemen SDM dengan strategi SDM perusahaan. Selain itu, tujuan studi ini adalah memastikan bagaimana kegiatan-kegiatan SDM dapat selaras dengan strategi SDM untuk meningkatkan kualitas pekerjaan departemen SDM dalam rangka pencapaian tujuan perusahaan. Studi dilakukan dengan melakukan kajian mendalam terhadap jurnal ilmiah yang ditulis dengan menggunakan pendekatan brainstorming kelompok interaktif, terdiri dari 21 mahasiswa ke dalam tiga kelompok untuk membahas dan menghasilkan ide-ide tentang kegiatan SDM dan hubungan strategis mereka sementara peneliti membimbing dan menyediakan bahanbahan yang dibutuhkan. Grup mengidentifikasi dan menyepakati tujuh kegiatan SDM termasuk desain pekerjaan; pengerahan; seleksi; retensi dan PHK; manajemen kinerja; pelatihan karyawan; dan kompensasi, dan selaras dengan masing-masing dari empat strategi SDM yang diidentifikasi meliputi Bargain Laborer; Free Agent; Loyal Solidier; dan Committed Expert. Hasil studi mengungkapkan adanya relevansi antara kegiatan departemen SDM dengan strategi SDM perusahaan. Total kinerja organisasi juga dapat dipengaruhi secara positif oleh kegiatan SDM melalui keterkaitan dengan strategi SDM perusahaan.
\end{abstract}

Kata kunci: aktivitas SDM, brainstorming interaktif berkelompok, strategi SDM, hubungan vertikal SDM, kinerja organisasi.

\section{PENDAHULUAN}

Praktik sumber daya manusia (SDM) yang baik akan berdampak pada kegiatan kinerja organisasi dan keunggulan kompetitif (Steward \& Brown 2011). Saat ini, SDM lebih berfokus pada penambahan nilai dan kebutuhan untuk meyelaraskan kegiatan SDM dengan perencanaan strategis. Menurut Thite (2012), fungsi SDM dalam organisasi yaitu membangun kemitraan bisnis manajer lini yang memiliki minat dan keterlibatan langsung pada SDM, maka fungsi SDM 
menjadi bagian integral dari unit bisnis strategis dan memberikan solusi dalam menyediakan layanan yang cepat dan efisien kepada mitra bisnis.

Terkait dengan konsep sumber daya manusia, diyakini bahwa organisasi harus memperoleh, mengembangkan, dan mempertahankan kompetensi karyawan dan praktik yang diperlukan untuk mengelola sumber daya tersebut (Darwish et al. 2013). Hal tersebut penting untuk organisasi apabila ingin bertahan hidup dan untuk bersaing secara efektif dalam ekonomi global saat ini, yang semakin menjadi berbasis pengetahuan. Gagasan ini telah menyebabkan penelitian tentang keterkaitan antara SDM dan kinerja organisasi.

Strategi dipandang sebagai
serangkaian pilihan dan tindakan
terkoordinasi yang memusatkan perhatian pada arah dan bagaimana cara mencapai tujuan yang ingin dicapai. Oleh karena itu strategi memerlukan metode pengambilan keputusan secara menyeluruh untuk memasukkan cara menempatkan pilihan menjadi praktik (Darwish et al 2013). Sehubungan dengan manajemen SDM ada dua bentuk strategi termasuk strategi bisnis yang kompetitif, yang berkaitan dengan pilihan dan tindakan tentang bagaimana caranya menyediakan kebutuhan pelanggan; dan strategi sumber daya manusia, yang melibatkan pilihan yang tepat dan tindakan tentang manajemen orang dalam organisasi. Untuk memastikan efektivitas organisasi, kedua strategi harus bekerja bersama.

Strategi manajemen sumber daya manusia atau strategic human resource management (SHRM) menjelaskan bagaimana manajemen SDM diselaraskan dengan tujuan strategis dengan tujuan untuk meningkatkan kinerja bisnis dan untuk mengembangkan budaya organisasi yang mendorong fleksibilitas dan inovasi (Javed 2017). Pentingnya SHRM diungkapkan oleh Darwish et al. (2013) yang melaporkan bahwa konsep tersebut, selama dekade terakhir, telah menarik banyak perhatian terutama karena dampak potensial pada fungsi organisasi bisnis. Perhatian yang diberikan SHRM ini tercermin dalam semakin pentingnya modal manusia dan perannya dalam mendapatkan keunggulan kompetitif dan meningkatkan kinerja organisasi.

Kegiatan SDM seperti rekrutmen, seleksi, pelatihan dan penghargaan terhadap pegawai dilakukan dengan tetap memperhatikan tujuan dan sasaran perusahaan, hal tersebut dapat didefinisikan oleh strategi. Selaras dengan kegiatan SDM, tujuan strategis perusahaan telah difasilitasi organisasi untuk mencapai target luar biasa (Thite 2012). Sejalan dengan hal tersebut, Nagaraj dan Kamalanabhan (2005) juga mengungkapkan perlunya hubungan antara perencanaan strategis dan manajemen SDM. Implikasinya, manajemen SDM perlu didekati dari sudut pandang strategis, yang membutuhkan hubungan antara praktik manajemen SDM dan strategi SDM.

Terdapat beberapa strategi SDM yang berfokus pada model strategi perusahaan yang ada. Contoh yang sering dikutip adalah jenis strategi Miles dan Snow (1978). Strategi diklasifikasikan sebagai "defender", "analiser" dan "prospector", yang dibangun berdasarkan pekerjaan awal pada strategi dan struktur. Selain itu, terdapat klasifikasi lain yang menguraikan tiga strategi yang terkait dengan Pfeffer (1998) yaitu strategi kompetitif umum termasuk strategi "biaya", "fokus" dan "diferensiasi". Strategi SDM yang digunakan dalam studi ini menggunakan kerangka kerja yaitu klasifikasi strategi yang didasarkan pada Stewart dan Brown (2011). Berdasarkan kerangka kerja tersebut dihasilkan empat strategi SDM terbentuk dari kombinasi arah strategis perusahaan dan orientasi kerja pegawai. Keempat strategi SDM tersebut dikembangkan dari dua pendekatan yang digunakan untuk menyelidiki pola sumber daya manusia. Pendekatan yang digunakan termasuk pendekatan universal dan pendekatan kontingensi (Delery and Doty 1996). Universalistik adalah pendekatan yang berupaya mengidentifikasi serangkaian praktik SDM yang bermanfaat bagi seluruh organisasi (Delery and Doty 1996). Tujuan dari 
pendekatan ini adalah untuk menemukan satu cara terbaik untuk menyelesaikan masalah manajemen orang yang diberikan. Pendekatan universalistik mengidentifikasi sekumpulan praktik yang tampaknya bermanfaat secara umum, dan juga memperlihatkan bahwa manajemen peduli dengan karyawan (Delery and Doty 1996). Pendekatan kontingensi berupaya menyelaraskan praktik sumber daya manusia dengan strategi bisnis yang kompetitif. Pendekatan ini berfokus pada pendekatan biaya vs diferensiasi (Delery and Doty 1996). Pendekatan "cost leadership" terutama berkaitan dengan pengurangan biaya dan menekankan proses serta aturan umum. Organisasi yang fokus pada diferensiasi berusaha untuk meningkatkan inovasi dan kualitas. Mereka menunjukkan minat dalam karir pengembangan sebagai sarana untuk mencapai hasil bisnis yang baik (Delery and Doty 1996).

Fitur lain yang membedakan dari pendekatan kontingensi adalah apakah suatu organisasi memiliki orientasi kerja internal atau eksternal (Stewart \& Brown 2011). Organisasi yang memiliki orientasi kerja internal mencari hubungan jangka panjang dengan karyawan, sedangkan organisasi yang menunjukkan orientasi kerja eksternal tertarik pada fleksibilitas dan tidak memiliki komitmen jangka panjang dengan karyawan. Dua set dimensi - "cost leadership" vs. diferensiasi, dan orientasi kerja internal vs eksternal orientasi kerja digabungkan untuk mengembangkan empat strategi SDM yang berbeda, yang meliputi "Loyal Soldier" ("cost leadership"/ tenaga kerja internal), "Bargain Labourer" ("cost leadership"/ tenaga kerja eksternal), "Free Agent" (diferensiasi / tenaga kerja eksternal) dan "Committed Expert" (diferensiasi / tenaga kerja internal).Empat strategi SDM tersebut disajikan pada Gambar 1.

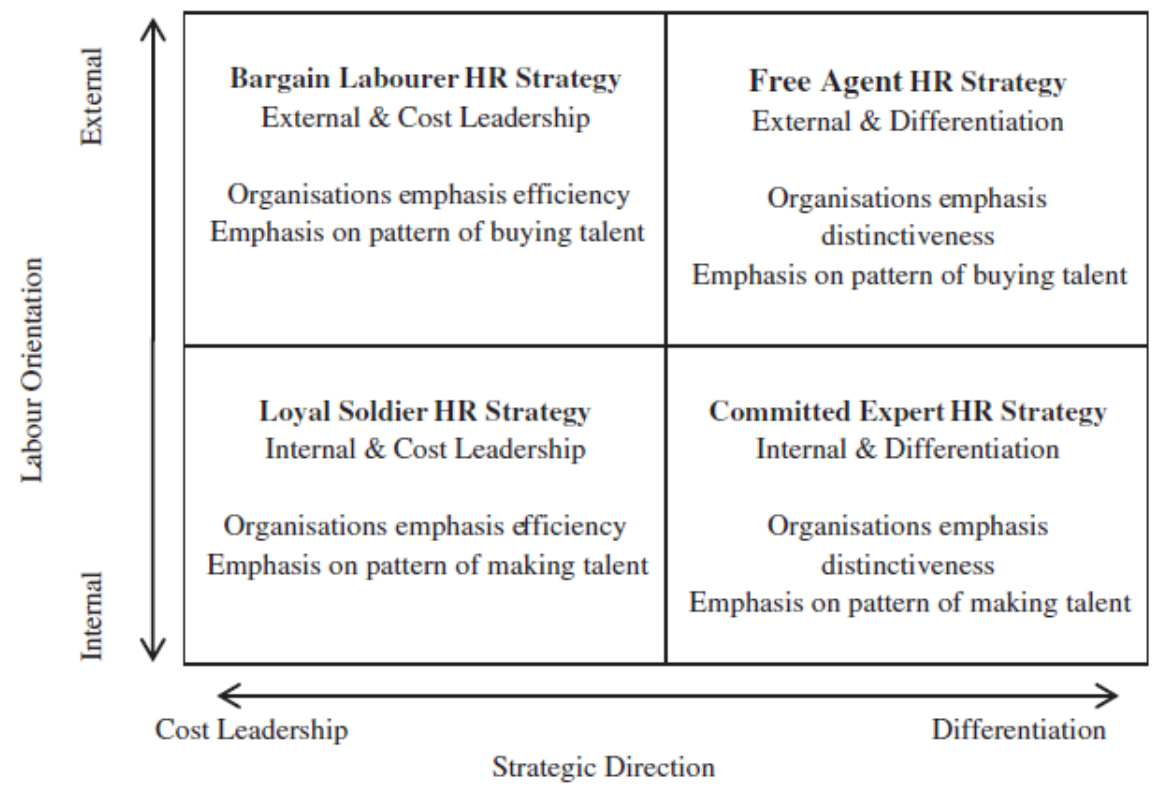

Gambar 1. Empat Strategi Manajemen SDM

\section{METODOLOGI}

\section{Metode}

Studi ini dilaksanakan dengan menggunakan metode kualitatif yakni studi menggunakan beberapa literatur terkait eksplorasi keterkaitan strategi SDM dan kegiatan SDM. Brainstorming berkelompok dilaksanakan untuk membahas mengenai materi bahasan oleh kelompok beranggotakan 4 orang. Kemudian dilakukan pembahasan dan diskusi mengenai hasil kajian oleh kelompok yang lebih besar yang beranggotakan 27 orang. Tulisan ini disusun berdasarkan hasil telaah literatur 
dan diskusi serta diakhiri dengan penarikan kesimpulan.

\section{Waktu Pelakasanaan}

Waktu pelaksanaan penelitian ini adalah bulan September 2019.

\section{DISKUSI DAN PEMBAHASAN}

Departemen SDM perlu menghubungkan kegiatannya dengan strategi SDM untuk memaksimalkan efektivitas kegiatan SDM untuk berkontribusi pada strategi perusahaan. Berdasarkan hasil kegiatan brainstorming strategi SDM dimasukkan ke dalam strategi perusahaan, apabila aktivitas SDM sudah strategis berarti operasi perusahaan juga strategis (Oppong 2017). Ini menyiratkan bahwa pentingnya strategi SDM untuk organisasi dapat diidentifikasi dengan bagaimana kegiatan SDM dilakukan; dan bagaimana kegiatan ini, diinformasikan oleh strategi SDM, terkait dengan strategi perusahaan (Oppong 2017). Kegiatan SDM umum yang diidentifikasi oleh kelompok peserta meliputi desain pekerjaan, rekrutmen, seleksi, retensi dan pemisahan, manajemen kinerja, pelatihan karyawan, serta kompensasi.

\section{Desain Pekerjaan}

Desain pekerjaan merupakan
proses pembagian tugas dan
koordinasi pekerjaan untuk para
karyawan (Stewart dan Brown 2011).
SDM dapat merancang berbagai
pekerjaan yang sejalan dengan
organisasi dengan tujuan mengejar
cost leadership atau differentiation
sehingga menghasilkan arah strategi
SDM bagi perusahaan (Stewart dan
Brown 2011). Jika perusahaan memiih
konsep cost leadership maka strategi
yang cocok untuk digunakan adalah
Loyal Soldier atau Bergaining
Labourer. Organisasi yang
menerapkan strategi ini lebih memiliki
kendali atas karyawannya. Sebagian
besar karyawannya tergolong kurang
terampil dan hanya memiliki sedikit
kebebasan dalam berpendapat dalam
menjalankan tugasnya (Stewart dan
Brown 2011). Sebaliknya, apabila
sebuah organisasi lebih mengejar

pada konsep differentiation sebagai arah strateginya, maka strategi yang tepat untuk digunakan adalah Committed Expert dan Free Agent. Strategi ini menerapkan kebebasan berpendapat dalam menjalankan tugasnya dan disesuaikan dengan keahlian masing-masing karyawan. Oleh karena itu pada strategi ini dibutuhkan karyawan yang ahli atau professional pada bidang pekerjaan tertentu (Stewart dan Brown 2011). Organisasi juga dapat menggunakan tenaga kerja dari luar organisasi untuk memeberikan suatu inovasi seperti contohnya konsultan.

2. Perekrutan Karyawan

Kegiatan ini melibatkan SDM pada proses mengindentifikasi dan menarik orang-orang yang mungkin bisa bekerja untuk organisasinya (Oppong 2017). Kegiatan ini membutuhkan strategi secara keseluruhan agar perekrutan karyawan dapat efektif. Tiga dimensi strategis dilihat dari lingkup keterampilan, sumber pelamar dan pratinjau pekerjaan. Sebuah organisasi yang berfokus pada keterampilan maka dapat berfokus memilih SDM berketerampilan khusus yang diharapkan dapat melakukan pekerjaan yang membutuhkan keahlian khusus (Oppong 2017). Strategi yang dapat digunakan adalah free agent dan committed expert. Strategi tersebut berupaya menarik sekelompok kecil pelamar dengan probabilitas tinggi memiliki kehalian khusus untuk menyelesaikan pekerjaan yang sulit seperti contohnya dokter dan insyinyur. Namun, untuk organisasi yang membutuhkan banyak karyawan dengan tujuan cost leadership, dapat menggunakan strategi Loyal Soldier atau Bergaining Labourer. Karyawan yang dipekerjakan tidak membutuhkan keahlian khusus dan dapat direkrut dalam jumlah besar, baik dari luar organisasi maupun dari dalam organisasi (Oppong, 2017).

3. Seleksi 
Sebagai tindak lanjut dari proses perekrutan, yang dirancang untuk meningkatkan jumlah pelamar yang kualifikasinya memenuhi persyaratan pekerjaan dan kebutuhan organisasi, seleksi adalah proses memilih dari antara pelamar yang diperkirakan menawarkan kontribusi tertinggi untuk organisasi (Oppong 2017). Memilih karyawan yang tepat dapat meningkatkan efektivitas praktik sumber daya manusia lainnya dan mencegah banyak masalah manajemen SDM. Selain itu, pemilihan karyawan yang cermat dapat membantu organisasi untuk terlibat dan mempertahankan bakat yang diperlukan untuk menghasilkan barang dan jasa untuk memenuhi harapan pelanggan.

Keputusan seleksi dapat didasarkan pada tiga dimensi berikut: keterampilan spesifik vs. umum; kecocokan pekerjaan vs. kecocokan organisasi; dan prestasi vs. potensi (Suliman dan lles 2000). Untuk memulainya, organisasi yang fokus pada keahlian spesialis atau generalis mendasarkan seleksi pada jangka pendek vs jangka panjang dengan keterampilan spesialis atau jangka panjang vs jangka pendek dengan keterampilan generalis. Karyawan jangka panjang mengembangkan hubungan jangka panjang dengan organisasi dan mengembangkan pemahaman yang lebih dalam tentang operasi dan praktik perusahaan (Javed et al 2017). Karyawan jangka pendek pindah dari satu organisasi ke organisasi lain tanpa mengembangkan keahlian tentang bagaimana hal-hal dilakukan pada pekerjaan tertentu (Oppong 2017). Karyawan menawarkan bakat spesialis ketika mereka telah mengembangkan keahlian di bidang tertentu, dan bakat generalis ketika mereka telah beroperasi di berbagai posisi. Kombinasi keterampilan ini dapat diselaraskan dengan strategi SDM secara keseluruhan (Oppong 2017).

4. Retensi dan Pemutusan Hubungan Kerja (PHK)
Karyawan adalah aset utama dari hampir setiap organisasi tetapi sulit untuk mengidentifikasi, merekrut, dan melatih karyawan yang baik bisa jadi mahal (Si and Li 2012).. Biaya dan konsekuensi negatif dari penggantian karyawan mendorong organisasi untuk memfokuskan upaya pada retensi karyawan dengan menempatkan serangkaian tindakan yang bertujuan mempertahankan karyawan yang baik begitu mereka dipekerjakan (Robbins et al 2009). Sementara mempertahankan karyawan yang baik itu bermanfaat, organisasi kehilangan uang ketika mereka mempertahankan karyawan yang buruk. Ini mengungkapkan fakta bahwa mengecilkan hati karyawan yang tidak produktif dari melanjutkan organisasi sama pentingnya dengan mempertahankan pekerja yang produktif (Oppong 2017). Selain itu, perubahan dalam kondisi ekonomi dan permintaan produk terkadang memaksa organisasi untuk berhemat, yang melibatkan proses mengakhiri hubungan kerja karyawan dengan organisasi secara efisien dan adil. Retensi karyawan sangat penting bagi organisasi yang mengejar strategi Loyal Soldier atau Committed Expert. Strategi Expert Committed SDM mendapatkan manfaat dari mempertahankan karyawan yang mengembangkan keterampilan khusus dan dapat membantu membangun tenaga kerja dengan keterampilan unik dan hubungan yang langgeng. Keterampilan ini sangat penting untuk menghasilkan produk dan layanan khas yang tidak dapat dengan mudah diduplikasi oleh pesaing (Oppong 2017) . Oleh karena itu jelas bahwa kegiatan retensi dan pemisahan perlu diselaraskan dengan arah strategis organisasi.

5. Manajemen kinerja

Manajemen kinerja adalah proses menghubungkan tujuan bisnis keseluruhan organisasi dengan tujuan departemen, tujuan tim, dan tujuan individu (Suliman 2007). Prosesnya melibatkan penetapan target; terus- 
menerus meninjau kemajuan menuju target tersebut; dan menawarkan tindakan perbaikan di mana ada kekurangan pelatihan / pengembangan (Heery \& Noon, 2010). Sebagian besar ukuran spesifik dari kinerja pekerjaan terkait satu sama lain dan mereka bergabung untuk menciptakan faktor kinerja umum yang menjadi ciri kontribusi keseluruhan bagi organisasi. Evaluasi kinerja dan memberikan umpan balik adalah alat yang diperlukan untuk meningkatkan kinerja karyawan, yang diterjemahkan menjadi kinerja organisasi yang lebih baik (Suliman2007). Untuk mencapai produktivitas yang lebih tinggi, manajemen perlu mendorong auditor untuk menetapkan tujuan, menilai kinerja, dan memberikan umpan balik kepada karyawan. Salah satu alasannya adalah bahwa kepercayaan dalam manajemen meningkat ketika kinerja diukur secara akurat dan dihargai secara memadai. Penilaian yang efektif, terutama penilaian yang memungkinkan partisipasi karyawan, telah dikaitkan dengan tingkat kepuasan kerja yang lebih tinggi. Dua elemen strategis diidentifikasi sehubungan dengan manajemen kinerja, ini termasuk sistem berbasis prestasi dan sistem berbasis paritas (Suliman2007).

Sistem berbasis prestasi menggunakan ukuran relatif dan distribusi paksa untuk mengenali kinerja tinggi (Heery \& Noon, 2010). Tujuan dari sistem berbasis prestasi adalah untuk mengembangkan dan mengenali kinerja tinggi untuk mencapai hasil kinerja yang unggul. Secara umum, pendekatan berbasis prestasi sangat cocok untuk organisasi yang mengejar strategi diferensiasi karena penekanan pada hadiah, pekerjaan yang menantang dan keterampilan yang tinggi untuk mendorong inovasi dan hasil berkualitas tinggi, sistem berbasis prestasi diselaraskan dengan organisasi yang mengejar strategi Free Agent atau Committed Expert SDM. Karyawan yang berkinerja buruk dapat didorong untuk meninggalkan organisasi untuk digantikan dengan orang lain yang memiliki keterampilan dan motivasi yang lebih besar. Sistem berbasis paritas menggabungkan langkah-langkah absolut dan distribusi gratis untuk mendorong kerja sama. Sistem ini biasanya lebih rendah biaya dan dapat mengenali sebagian besar karyawan sebagai karyawan berkinerja tinggi, dan oleh karena itu paling selaras dengan Bargain Laborer dan Loyal Soldier SDM, yakni strategi yang berfokus pada cost leadership yang mendorong pekerjaan yang saling tergantung (Oppong 2017).

\section{Pelatihan karyawan}

Pelatihan adalah upaya yang diperhitungkan oleh organisasi untuk mengubah keterampilan, sikap, dan pengetahuan karyawan dengan tujuan meningkatkan tingkat kompetensi mereka, seperti diskusi online dengan kolega dari berbagai situs perusahaan atau dari seluruh negeri; kuliah kelompok besar yang diberikan oleh seorang ahli; proyek kelompok kecil yang dikoordinir oleh perwira senior; atau simulasi yang dipandu oleh program komputer, dll (Susanne et al 1994). Fitur penting dari pelatihan adalah bahwa karyawan dibentuk untuk menjalani pengalaman struktural yang membantu mereka mempelajari sesuatu yang dapat diterapkan untuk meningkatkan kinerja pada tugas / pekerjaan tertentu. Pelatihan yang dirancang dan disampaikan dengan baik dapat meningkatkan efektivitas keseluruhan organisasi dalam tiga cara: (1) meningkatkan komitmen dan motivasi karyawan; (2) membantu karyawan melakukan pekerjaan mereka secara lebih efektif dan efisien; dan (3) memberi manfaat bagi organisasi dengan membantu mereka memenuhi tujuan strategis (Oppong, 2017) .

Pelatihan juga dapat dikaitkan dengan strategi untuk membantu organisasi memperoleh keunggulan dibandingkan organisasi yang bersaing. Kebutuhan dan sumber daya pelatihan bervariasi di setiap perusahaan tergantung pada strategi 
yang dikejar perusahaan. Ketika perusahaan mengikuti strategi cost leadership, pelatihan harus membantu karyawan memecahkan masalah dan menjadi lebih efisien karena strategi mengharuskan karyawan memiliki pengetahuan, keterampilan, dan sikap yang membantu menjadi rendah biaya dan meningkatkan efisiensi. Di sisi lain, perusahaan yang mengejar strategi diferensiasi dapat menggunakan pelatihan untuk membantu karyawan memberikan layanan yang lebih baik atau menjadi lebih inovatif dan kreatif. Oleh karena itu free agent harus menawarkan pelatihan kepada karyawan yang akan mengharuskan mereka untuk memberikan layanan atau membuat produk yang lebih unggul dari yang ditawarkan oleh pesaing (Suliman 2007). Dalam hal jumlah keseluruhan pelatihan, organisasi dengan orientasi kerja internal akan menawarkan lebih banyak pelatihan daripada organisasi dengan orientasi kerja eksternal karena perbedaan keterampilan dan komitmen terhadap organisasi. Misalnya, karyawan internal biasanya tidak terampil dan banyak organisasi ingin bergantung pada tenaga kerja internal alih-alih mencari yang sudah maju dan terampil yang mungkin memerlukan sedikit atau tidak ada pelatihan. Di sisi lain, organisasi dengan orientasi tenaga kerja eksternal akan lebih suka memperoleh pengetahuan dan keterampilan baru dengan mempekerjakan profesional baru tetapi terampil (Stewart \& Brown 2011).

\section{Kompensasi}

Kompensasi adalah sistem yang melibatkan proses administrasi dan pengelolaan. Kompensasi mencakup tunjangan lain seperti tabungan pensiun, cuti dibayar, dan asuransi dari pekerjaan Oppong (2017). Sistem kompensasi sangat penting bagi organisasi atau perusahaan karena memiliki potensi atau daya untuk menarik dan memberi harapan kepada karyawan. Pembayaran kompensasi yang adil dapat meningkatkan motivasi dan kontribusi karyawan. Terdapat dua dimensi strategis dalam melakukan kompensasi (Suliman and Iles 2000). Pertama, kompensasi seragam yaitu pemberian yang dilakukan tanpa memandang tingkat kinerja untuk membangun rasa kerja sama tim. Kedua, kompensasi variabel yaitu menekankan pembayaran berdasarkan kinerja yang dilakukan. Jika kinerja yang dilakukan karyawan dinilai tinggi maka akan mendapat kompensasi yang lebih. Pada dimensi kedua ini, menyangkut pada komitmen transaksional maupun relasional. Komitmen transaksional berfokus pada pembayaran jangka pendek dan bonus, sedangkan komitmen relasional menekankan kepada insentif jangka panjang serta dukungan psikologis dari perusahaan (Suliman 2007) . Jika diaplikasikan pada strategi SDM ahli, maka yang cocok dilakukan adalah dengan dimensi kompensasi variabel, karena lebih menghargai kinerja yang dilakukan karyawan dan dapat membangun hubungan jangka panjang.

Hasil studi ini sejalan dengan studi sebelumnya yang dilakukan oleh AlHawashim (2013). Al-Hawashim memperoleh hasil bahwa persepsi karyawan terhadap strategi SDM mempengaruhi sikap dan kepuasan karyawan dalam bekerja. Kemudian dengan menggunakan pendekatan yang sama dengan studi yang dilakukan Oppong (2017) yaitu teori Stewart \& Brown (2011) Al-Hawashim membahas pendekatan-pendekatan yang berbeda dalam mengelola karyawan. Gambar 2 menggambarkan empat respons yang berbeda satu sama lain di sepanjang dua dimensi: konstruktif / destruktif dan aktif / pasif.

Seorang pekerja yang tidak puas menyampaikan ketidakpuasannya dengan cara-cara berikut: 


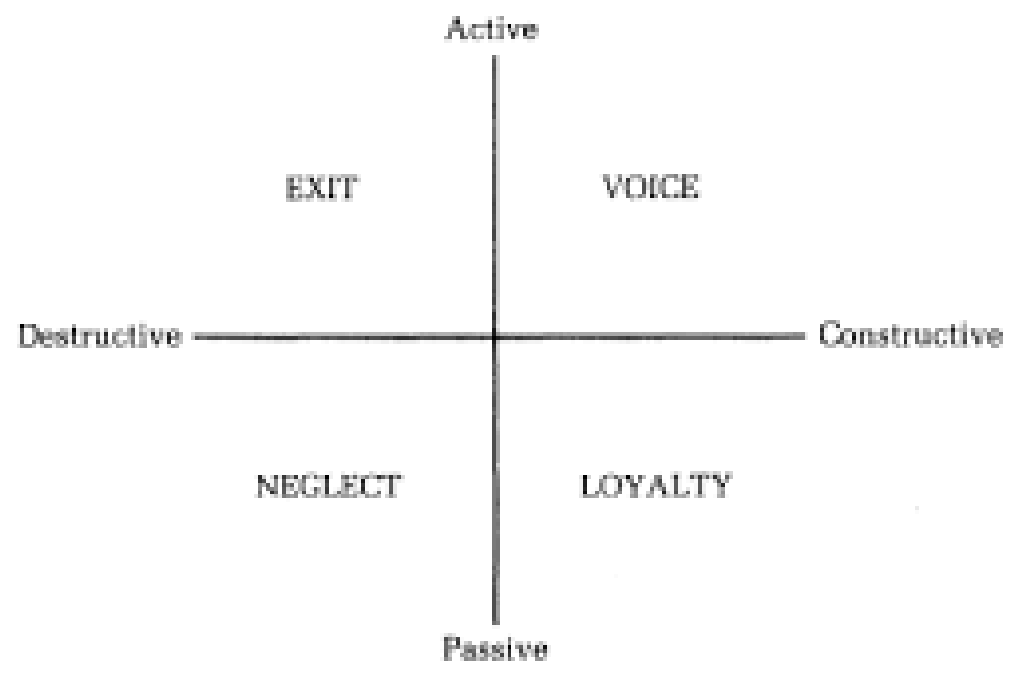

\section{Gambar 2. Cara karyawan untuk mengekspresikan ketidakpuasan}

\section{Exit Behaviours}

Respons yang paling mungkin terhadap ketidakpuasan ditandai oleh peningkatan tingkat turnover. Karyawan mungkin merasa harus membangun kembali diri mereka sendiri di tempat baru daripada mandek di organisasi saat ini. Jika seorang karyawan dengan kinerja luar biasa membuat keputusan untuk meninggalkan pekerjaan. Maka departemen SDM akan mengumumkan posisi kosong ini dengan kompetensi serupa. Proses penggantian anggota tim kemungkinan besar akan mengganggu produktivitas seluruh tim. Sebagai contoh, tim sepak bola membutuhkan waktu tertentu untuk mensinergikan upaya antara anggota dan penarikan tinggi dari tim akan mempengaruhi kesuksesan mereka. Dengan demikian, organisasi ingin mempertahankan tenaga kerja mereka untuk mempertahankan produktivitas tinggi.

Selanjutnya, proses rekrutmen dan seleksi akan menghabiskan waktu dan uang. Selain itu, upaya induksi dan pelatihan untuk karyawan baru akan membutuhkan upaya tinggi dari karyawan saat ini (Oppong, 2017) . Pencegahan terhadap hal tersebut, organisasi dapat menerapkan program retensi yang bertujuan untuk mengurangi turnover dan meningkatkan efisiensi.

Karyawan yang terlatih dan produktif dengan kompetensi yang tepat akan memiliki probabilitas tinggi untuk mendapatkan pekerjaan yang lebih baik (Javed et al. 2017). Headhunter menargetkan karyawan produktif saat ini bahkan jika mereka tidak aktif dalam mencari pekerjaan. Banyak organisasi memiliki kepedulian yang tinggi terhadap manajemen retensi. Perusahaan memahami nilai karyawan dan pengaruh turnover tinggi pada daya saing dan profitabilitas. Darah baru akan sangat penting untuk mendapatkan ide dan strategi baru. Perusahaan yang dikelola dengan baik akan mempertahankan tingkat turnover yang dapat diterima dan merekrut karyawan baru yang kemungkinan besar akan bertahan lama (Stewart \& Brown 2011, hal.250).

Persepsi individu tentang organisasi dan ekspektasi dari atasan akan memengaruhi perilaku karyawan (Robbins \& Judge 2009, p.174). Dalam banyak kasus, karyawan dengan kompensasi yang kurang dari yang diharapkan akan memiliki niat berhenti yang tinggi (Bratton \& Gold 2007, hal.205). Exit behaviours adalah respons terhadap meninggalkan pekerjaan dengan mencari pekerjaan baru dan mengundurkan diri (Robbins \& Judge 2009, p.121).

$$
\text { Faktor lain yang harus }
$$
dipertimbangkan mempengaruhi exit behaviours seperti desain pekerjaan yang harus memenuhi harapan (Bratton \& Gold 2007). Jumlah tantangan, pengaturan tugas dan otonomi dalam pengambilan keputusan juga merupakan faktor 
signifikan yang mempengaruhi persepsi karyawan dengan exit behaviour.

Hubungan intrapersonal dan interaksi dengan anggota tim akan mempengaruhi exit behaviours. Manusia perlu diterima dari masyarakat dan ingin mendapat perhatian yang memadai. Manajer harus memberikan pelatihan yang cukup dan peluang pengembangan kepada karyawan untuk memenuhi kebutuhan dasar mereka (Bratton \& Gold 2007, p. 205).

Exit behaviours juga dipengaruhi oleh faktor psikologis dan sosial seperti pertemanan dan hubungan yang terbangun selama ini. Dalam banyak kasus karyawan akan berkomitmen untuk organisasi mereka karena mereka membangun hubungan yang kuat yang akan hilang ketika mereka mengubah pekerjaan mereka saat ini. Untuk alasan ini beberapa organisasi berusaha untuk menarik bakat melalui penciptaan budaya terbuka yang menyambut anggota tim baru. Akhirnya, praktisi SDM melakukan upaya tinggi untuk mendemotivasi perilaku keluar dan memotivasi perilaku positif lainnya seperti voice behaviours (ekspresif) (Robbins \& Judge 2009, p.121).

\section{Voice Behaviours}

Seorang karyawan dapat mendiskusikan masalah ketidakpuasan dengan atasan untuk mengetahui cara peningkatan yang lebih baik. Voice behaviours adalah perilaku ekspektasi yang menyoroti komunikasi solusi yang membantu untuk masalah di dalam organisasi dengan maksud untuk memperbaiki situasi daripada kritik yang merusak (LePine dan Dyne 1998). Perilaku ini mungkin tidak dinyatakan dalam kebijaksanaan pekerjaan karyawan atau tugas yang diberikan. Misalnya, ketika pekerja menyarankan perbaikan inovatif dalam proses produksi yang meningkatkan produktivitas, kualitas, atau menurunkan biaya (LePine dan Dyne 1998).

Karyawan yang memiliki perilaku ini sedang mengevaluasi situasi saat ini. Kemudian, mereka menyadari bahwa pendapat mereka tidak sesuai dengan tindakan dengan kondisi yang ada. Dengan demikian, mereka akan menyarankan, mendiskusikan dan bekerja sama dengan orang lain untuk menemukan perbaikan yang sesuai dengan apa yang mereka yakini sebagai tantangan bagi organisasi (Robbins \& Judge 2009, hal.121).

LePine dan Dyne berpendapat (1998) bahwa voice behaviours adalah reaksi terhadap ketidakpuasan dengan sisi tertentu dari pekerjaan tetapi dengan peringkat tinggi dari kepuasan kerja umum atau kepuasan kerja sebelumnya. Beberapa orang lainnya memperdebatkan perilaku ini akan dimotivasi jika karyawan didorong untuk berbicara dari atasan mereka, atasan tersebut harus memiliki wewenang atau pemberdayaan untuk menghargai karyawan atas perbaikan dan rekomendasi mereka (Detert dan Burris 2007).

Bagaimana karyawan mengonseptualisasikan atau memahami batasan tugas adalah aspek lain. Individu di perusahaan dapat mengenali perilaku seperti itu sebagai normal atau bagian dari pekerjaan (Jacqueline et.al.2004). Deskripsi tugas kerja dan bagaimana organisasi menyatakannya merupakan bagian penting dalam pemahaman pekerjaan.

Jika karyawan percaya bahwa kegiatan kerja tambahan ini berada dalam batas pekerjaan mereka atau setidaknya sebagai integrasi dari tugas mereka, perilaku karyawan akan lebih terlibat dalam perilaku saran daripada jika mereka menganggapnya sebagai pekerjaan tambahan. Ketidakjelasan dalam uraian tugas dan definisi pekerjaan yang longgar dapat memiliki pengaruh positif pada konseptualisasi pekerjaan. Oleh karena itu, karyawan akan mengakui pekerjaan tambahan itu penting (Detert dan Burris 2007).

\section{Loyalty Behaviours}

Loyalty behaviours adalah perilaku optimis di mana karyawan melihat ke depan untuk masa depan organisasi, kondisi saat ini akan lebih baik bahkan jika mereka tidak mencapai tingkat kepuasan (Robbins \& Judge 2009, p.121). Karyawan 
yang optimis mempertahankan posisi organisasi dan percaya bahwa manajemen puncak akan membuat keputusan yang tepat (Robbins \& Judge 2009, hal.121).

Pekerja yang loyal terus dengan kinerja terbaik mereka dalam tugas-tugas mereka saat ini sementara organisasi menghadapi tantangan tertentu. Tantangan-tantangan ini dapat mempengaruhi tekanan kerja karyawan atau menahan kenaikan untuk waktu tertentu. Dapat dipahami bahwa beberapa individu dapat tetap loyal kepada majikan dengan kepuasan rendah karena alasan pribadi (Allen dan Tuselmann 2009). Karyawan lain dapat menutupi tugas untuk posisi yang kosong dan menerima kesulitan dengan tujuan peluang promosi di masa depan (Allen dan Tuselmann 2009). Karyawan dengan loyalty behaviours mengharapkan peningkatan dalam waktu dekat dan kondisi akan kembali menyenangkan seperti periode sebelumnya (Si dan Li 2012). Dengan demikian, mereka menerima penderitaan sementara dan juga mampu membayar kembali sebagian dari kepuasan kerja sebelumnya (Si dan Li 2012).

Mirip dengan loyalty behaviours, sikap komitmen organisasi adalah bahwa karyawan mengidentifikasi tujuan perusahaan dan ingin menjaga hubungan dengan organisasi mereka (Robbins \& Judge 2009, hal.113). Karyawan yang berkomitmen efektif akan loyal kepada organisasi karena kecocokan antara kepercayaan dan nilai-nilai pribadi dan perusahaan (Robbins \& Judge 2009, hal.113). Selain itu, karyawan yang berkomitmen normatif akan menjaga anggota organisasi dalam kondisi apa pun yang sesuai dengan etika dan moral pribadi (Robbins \& Judge 2009, hal.113). Perilaku loyalitas dan sikap komitmen bersifat konstruktif dan produktif. Suliman \& Iles (2000) menemukan bahwa karyawan dengan sikap komitmen afektif dapat mengarah pada peningkatan kinerja pekerja. Padahal, mereka tidak menemukan cukup bukti yang mendukung hubungan antara komitmen normatif dan produktivitas. Meskipun demikian, semua organisasi, kemungkinan besar, menargetkan agar karyawan yang loyal terus melakukan tugas mereka dalam kondisi sulit serta kondisi yang lebih disukai (Suliman \& Iles 2000)

\section{Neglect Behaviours and Feeling of Payback}

Beberapa karyawan mungkin sering menunjukkan ketidakhadiran, terlambat datang ke kantor, mengambil waktu istirahat yang lama, meningkatkan tingkat kesalahan dan mengurangi kinerja mereka. Exit behaviours dan neglect behaviours adalah perilaku yang destruktif, sedangkan voice behaviours dan loyalty behaviours adalah perilaku yang konstruktif (Robbins \& Judge 2009).

Neglect behaviours dimulai ketika pekerja mengurangi komitmen pekerjaan mereka dengan melakukan lebih sedikit upaya saat melakukan tugas pekerjaan. Selain itu, tingkat absensi yang tinggi, hingga keterlambatan tugas yang diberikan merupakan indikator untuk karyawan neglect behaviours. Karena kinerjanya rendah, karyawan dengan perilaku ini tidak akan kooperatif apalagi membantu rekan kerja. Singkatnya, penarikan karyawan kurang komitmen, produktif rendah, tidak kooperatif dan tidak menghormati aturan kehadiran (Stewart \& Brown 2011, hal.260). Banyak karyawan yang tidak puas yang mencapai tingkat penarikan kemungkinan besar akan memutuskan untuk berhenti. Namun, pekerja yang tidak puas dan yang ditarik ini tidak akan berhenti tetapi mereka akan terus bekerja tanpa keterlibatan. Kurangnya keterlibatan karyawan akan mengurangi keterlibatan dalam tugastugas pekerjaan dan antusiasme (Robbins \& Judge 2009, p.117). Alasan di balik terus bekerja tanpa hasrat adalah karena alasan finansial dan emosional yang akan hilang ketika mereka memutuskan untuk berhenti. 
Demikian pula, kelanjutan komitmen akan memengaruhi karyawan untuk menetap sebagai imbalan atas kompensasi finansial mereka. Namun, komitmen ini akan hilang jika mereka berhasil dan mendapatkan pekerjaan yang lebih baik dengan gaji yang lebih tinggi (Stewart \& Brown 2011, hal.260). Namun, kita dapat melihat bahwa suara dan kesetiaan adalah reaksi positif dalam cara orang mencoba untuk menstimulan atau mempertahankan keadaan pekerjaan yang menyenangkan, sementara exit behaviours dan neglect behaviours dianggap respons yang tidak membantu (Si dan Li 2012). Dari sudut pandang lain, exit behaviours dan voice behaviours dari karyawan membuat upaya mereka untuk mengelola kepuasan rendah mereka, tetapi loyalitas dan pengabaian lebih cenderung negatif dan distributif (Si dan $\mathrm{Li}$ 2012).

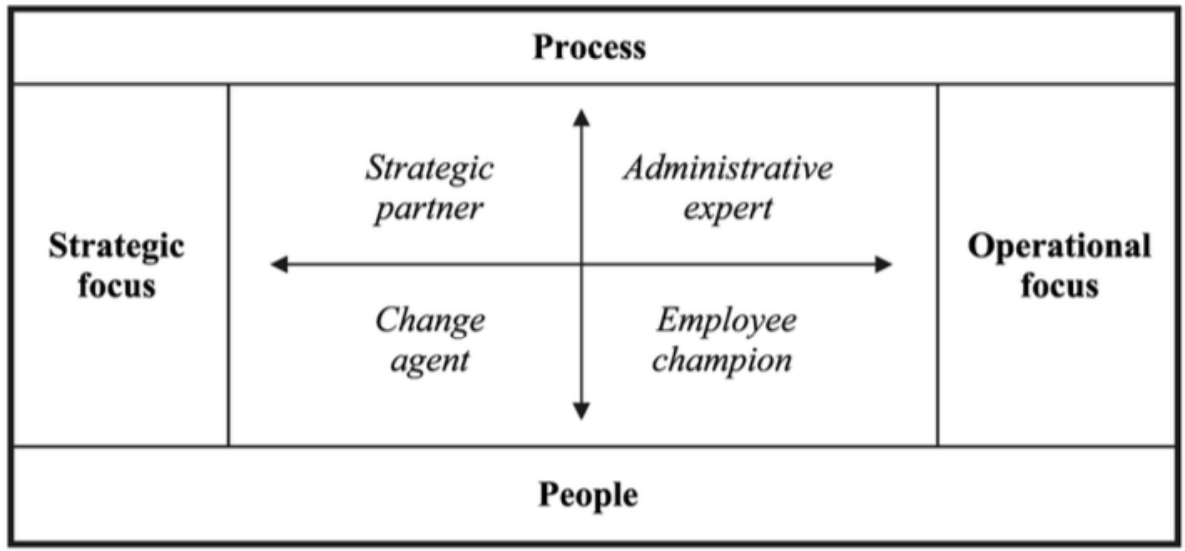

Source: Ulrich (1997)

Gambar 3. Fungsi SDM dalam perusahaan

$\begin{array}{ll} & \text { Fungsi-fungsi manajemen SDM } \\ \text { luas, di mana fungsi-fungsi ini }\end{array}$ menargetkan proses pembentukan untuk mengelola orang dalam jangka pendek dan jangka panjang (Stewart \& Brown 2011, p.19). Tim SDM adalah referensi bagi karyawan untuk mempelajari tentang fungsi departemen mereka dan prosedur administrasi (Alfes et. Al. 2010). Selain itu, tim SDM adalah "employee champion", peran mereka akan sebagai penengah yang akan menerima keluhan dan klaim dari karyawan untuk memastikan bahwa mereka diperlakukan dengan adil (Stewart \& Brown 2011, p.19). Selain itu, salah satu peran efektifnya adalah penggagas perubahan yang akan mengembangkan organisasi dan modal manusia untuk menghadapi dan selamat dari ancaman di masa depan (Alfes et. Al. 2010).

Keempat fungsi yang akan difokuskan adalah "strategic partner". Tim SDM bekerja sama dengan departemen lain dan manajemen puncak untuk mencapai tujuan strategis organisasi (Alfes et. Al. 2010). Dengan memberikan solusi yang cocok untuk risiko internal dan eksternal, tim SDM memainkan peran sebagai strategic partner (Stewart \& Brown 2011, p.19). Akibatnya, perusahaan akan menggunakan sumber daya organisasi secara efektif untuk mempertahankan keunggulan kompetitif mereka. 
Organisasi bertujuan untuk menjaga bisnis dalam industri mereka tetap layak secara ekonomi. Mempertahankan laba yang cukup untuk melanjutkan siklus hidup organisasi adalah tujuan ekonomi utama manajemen SDM (Boxall dan Purcell 2007, p.11). Tim SDM yang efektif akan memastikan bahwa mereka mempertahankan dan mengembangkan karyawan yang produktif dengan biaya dan jumlah karyawan yang minimum (Boxall dan Purcell 2007, hal.14).

Selain itu, mempertahankan organisasi yang layak secara ekonomi harus fleksibel terhadap perubahan. Untuk meningkatkan fleksibilitas, beberapa adopsi diharapkan dapat diimplementasikan dari waktu ke waktu dengan efek minimum pada aktivitas utama organisasi (Boxall dan Purcell 2007, hal.14). Praktik SDM dapat diadaptasi sesuai dengan kondisi ekonomi.

Dalam jangka panjang manajemen SDM harus memberikan kelincahan dalam strategi mereka untuk diubah secara dramatis dalam menanggapi perubahan lingkungan misalnya biaya dan teknologi. Salah satu contohnya yaitu Kodak yang pembuat film fotografi terkenal di tahun 1970-an yang mendominasi pasar pada waktu itu adalah salah satu organisasi yang tidak dapat bertahan karena perubahan dramatis dalam teknologi dari film ke kamera digital (Boxall dan Purcell 2007, hal.14). Praktik manajemen SDM harus memperbarui pengetahuan karyawan dan menarik bakat yang akan membantu organisasi untuk mempertahankan daya saingnya. Contoh lain tetapi dengan adopsi yang berhasil adalah IBM di mana ia gesit dengan mentransfer pabriknya ke Cina untuk menjaga biaya tenaga kerja tetap rendah.

Namun, organisasi tidak boleh mengabaikan tanggung jawab sosial perusahaan mereka manajemen SDM dapat mengelola operasi organisasi untuk mematuhi undang-undang setempat dan memberikan legitimasi sosial (Boxall dan Purcell 2007, hal.17). Misalnya, kondisi kerja karyawan harus memenuhi persyaratan minimum sesuai dengan undang-undang ketenagakerjaan. Juga, gaji penting untuk menjadi lebih tinggi atau sama dengan pembayaran minimum di negara itu. Beberapa praktik etika akan disarankan untuk diterapkan, misalnya kesempatan kerja yang setara, menjaga lingkungan yang bersih, harga pembelian yang adil dan dukungan organisasi amal.

Tim SDM berwenang untuk menggunakan kekuatan untuk meningkatkan otonomi dan mengarahkan karyawan ke arah perilaku yang diinginkan. SDM akan menetapkan tindakan disipliner yang dinyatakan untuk menerapkannya ketika seorang karyawan atau kelompok karyawan menolak rantai komando (Boxall dan Purcell 2007, hal.18). Meningkatkan otonomi organisasi adalah tujuan tambahan dari berbagai tujuan vital yang telah disediakan oleh praktik manajemen SDM.

Tujuan manajemen SDM bervariasi dari menciptakan sistem manajemen karyawan yang efektif biaya hingga menciptakan legitimasi sosial dalam lingkungan operasi (Boxall dan Purcell 2007, hal.29). Selain itu, penargetan manajemen SDM untuk mempertahankan organisasi yang fleksibel membuat perubahan dramatis tanpa mempengaruhi bisnis inti (Boxall dan Purcell 2007, hal.29).

Pentingnya keterkaitan antara strategi SDM dan kegiatan yang dilakukan oleh departemen SDM diharapkan dapat memberikan manfaat terhadap pencapaian tujuan serta sesuai dengan arah strategi perusahaan. Studi yang dilakukan oleh Al-Hawashim (2013) mendasari hal tersebut dengan mengkaji keterkaitan antara strategi SDM dengan perilaku karyawan dalam bekerja sehingga perlunya penyesuaian antara pendekatan-pendekatan yang dilakukan dalam mengelola karyawan atau dapat dikatakan sebagai aktivitas yang 
dilakukan oleh departemen SDM. Hal ini juga diperkuat oleh studi yang dilakukan oleh Javed et al. (2017) mengenai hubungan positif antara penerapan strategi FHRM terhadap perilaku kerja yang inovatif karyawan hingga dampaknya terhadap tingkat inovasi perusahaan.

Studi yang dilakukan oleh Javed et al. (2017) menggambarkan bahwa FHRM secara positif dan signifikan berpengaruh terhadap innovative work behavior. Hasil ini mengindikasikan bahwa karyawan mampu meningkatkan keterampilan, perilaku, dan peranannya sehingga dapat beradaptasi dengan kebutuhan dan dapat meningkatkan perilaku kerja inovatif. Innovative work behavior secara positif dan signifikan berpengaruh terhadap firm innovativeness. Hasil ini mengindikasikan bahwa karyawan yang dapat meningkatkan perilaku kerja inovatif mampu bekerjasama dengan baik dalam lingkungan internal dan eksternal perusahaan. Selain itu, FHRM secara positif dan signifikan berdampak terhadap firm innovativeness. Hasil ini berbanding lurus dengan penelitian sebelumnya yang dilakukan ditahun 2013. Selanjutnya, hasil penelitian menunjukkan innovative work behavior mampu memediasi hubungan antara FHRM dan firm innovativeness. Hasil ini mengindikasikan bahwa inovasi perusahaan bergantung pada ide-ide yang dihasilkan dari kreatifitas karyawan.

Flexible Human Resource Management (FHRM) merupakan elemen penting dalam strategi manajemen SDM. Konsep ini diciptakan pada tahun 1995 oleh seorang bernama Sanchez yang menemukan bahwa FHRM dapat mengubah kondisi lingkungan pekerjaan dengan meningkatkan fleksibilitas kemampuan karyawan, kebiasaan, dan fungsinya. Menurut Chen \& Li (2015) terdapat perbedaan antara metode manajemen SDM tradisional dan manajemen SDM fleksibel. Manajemen SDM tradisional berfokus pada efektifitas dan efisiensi perusahaan, sedangkan manajemen SDM fleksibel berfokus pada peningkatan inovasi, daya saing, dan kemampuan adaptasi perusahaan.

\section{SIMPULAN}

Hasil studi mengungkapkan relevansi antara kegiatan individu departemen SDM dengan strategi SDM. Total kinerja organisasi dapat dipengaruhi secara positif oleh kegiatan SDM melalui keterkaitannya dengan strategi SDM. Oleh karena itu, fungsi SDM harus dianggap sebagai bagian kesatuan dari unit bisnis strategis, dan SDM diperlukan untuk menyesuaikan solusi untuk memberikan layanan yang cepat dan efisien. Keterkaitan antara strategi SDM dan kegiatan yang dilakukan oleh departemen SDM dapat memberikan dampak positif terhadap pencapaian tujuan serta sesuai dengan arah strategi perusahaan. Hal tersebut didasari oleh keterkaitan antara strategi SDM dengan perilaku karyawan dalam bekerja sehingga perlu penyesuaian antara pendekatan-pendekatan yang dilakukan dalam mengelola karyawan atau dapat dikatakan sebagai aktivitas yang dilakukan oleh departemen SDM. Terdapat hubungan positif antara penerapan strategi FHRM terhadap perilaku kerja yang inovatif karyawan sehingga berdampak terhadap tingkat inovasi perusahaan.

\section{REKOMENDASI}

Studi ini telah berhasil mengidentifikasi strategi dan kegiatan SDM dan bagaimana kaitannya dengan peningkatan pekerjaan departemen SDM hingga dampak terhadap peningkatan kinerja perusahaan. Karena penelitian ini terbatas pada implikasi strategis dari kegiatan SDM tetapi tidak meluas ke strategi perusahaan yang lebih luas, penelitian lebih lanjut disarankan tentang bagaimana Strategi SDM-aktivitas HR menghubungkan dampak pada strategi keseluruhan organisasi. 


\section{DAFTAR PUSTAKA}

Alfes, K., A. Shantz. C. Truss \& E. C. Soane. 2013. The link between perceived human resource management practices, engagement and employee behaviour: a moderated mediation model. The International Journal of Human Resource Management. Vol. 24 No. 2. Pp: 330-51.

Alfes, K., C. Truss, dan J. Gill. 2010. The sdm manager as change agent: evidence from the public sector. Journal of Change Management. Vol.10 No.1. pp:109-27.

Allen, M. and H. J. Tuselmann. 2009. All powerful voice? The need to include "exit", "loyalty" and "neglect" in empirical studies too. Employee Relations. Vol. 31 No.5. pp. 538-52.

Boxall, P. and J. Purcell. 2007. Strategy and Human Resource Management. Houndmills: Palgrave Macmillan Publishers.

Boxall, P., J. Purcell, and P Wright. 2007. Human Resource Management. Oxford: Oxford University Press.

Bratton, J. and J. Gold. 2007. Human Resource Management Theory and Practice. Houndmills: Palgrave Macmillan Publishers.

Detert, J.R. and E. R. Burris. 2007. Leadership behavior and employee voice: is the door really open? Academy of Management Journal. Vol. 50. No. 4. pp. 869-84.

Jacqueline, A.M., C. I. ShapiroKessler and J. Purcell. 2004. Exploring organizationally directed citizenship behaviour: reciprocity or 'it's my job'?
Javed, A., M. Anas, M. Abbas, A. I. Khan. 2017. Flexible human resource management and firm innovativeness: the mediating role of innovative work behavior. Journal of Human Resource Management. Vol. 20. No.1.

LePine, J. A. and L. V. Dyne. 1998. Predicting Voice Behavior in Work Groups, Journal of Applied Psychology Vol. 83 No.6. pp. 853-68.

Oppong, N.Y. 2017. Exploring the importance of human resource activities-strategies alignments: Interactive brainstorming groups approach. Cogent Business \& Management. Vol. 4. Pp:1-12.

Robbins, S., T. A. Judge, and T. Campbell. .2009. Organizational Behavior. (13th International Edition) Prentice Hall, London.

Stewart G.L. and K.J. Brown. 2011. Human Resource Management Linking Strategy to Practice. Danver: John Wiley \& Sons.

Suliman, A., and P. Iles. 2000. Is continuance commitment benefit to organizations? Commitment-performance relationship: a new look. Journal of Managerial Psychology, Vol.15 No.5. pp. 407-26.

Suliman, A.M.T.2007. Link between justice, satisfaction, and performance in the workplace. Journal of Management Development, Vol.26. No.4. pp.294-311.

Thite, M. 2012. Strategic global human resource management: case study of an emerging indian multinational. Human Resource Development International, Vol.15. Pp: 239247. 